DOI: $10.15193 /$ zntj/2020/125/359

\author{
MARTYNA WOŹNIAK, PAWEŁ SIUDEM, KATARZYNA PARADOWSKA
}

\title{
WLAŚCIWOŚCI PRZECIWUTLENIAJĄCE ORAZ ZAWARTOŚĆ KAPSAICYNOIDÓW W WYBRANYCH PRZYPRAWACH Z DODATKIEM OSTREJ PAPRYKI, DOSTĘPNYCH NA POLSKIM RYNKU
}

\author{
Streszczenie
}

Przyprawy stanowią istotny składnik diety. Ostra papryka jest powszechnie używana jako przyprawa kuchenna. Korzyści z jej stosowania wiążą się nie tylko z walorami smakowymi, ale także z pozytywnym wpływem prozdrowotnym. Jest to związane ze związkami polifenolowymi oraz innymi związkami o właściwościach przeciwutleniających zawartymi w owocach ostrej papryki, na przykład z kapsaicyną. Celem pracy było określenie zawartości związków polifenolowych, w tym flawonoidów, kapsaicynoidów oraz właściwości przeciwutleniających i zdolności redukowania jonów żelaza w przyprawach zawierających paprykę ostrą, dostępnych na polskim rynku. Z 7 różnych przypraw oznaczonych przez producentów jako ,papryka ostra”, ,chili” lub ,pieprz cayenne” oraz z papryki jalapeño z uprawy w warunkach domowych przygotowano ekstrakty wodno-etanolowe. Oznaczono w nich całkowitą zawartość związków polifenolowych (metodą Folina-Ciocalteu'a) oraz flawonoidów. Wykonano również testy przeciwutleniające FRAP i DPPH` oraz oznaczono spektrofotometrycznie zawartość kapsaicynoidów w przeliczeniu na kapsaicynę. Przyprawy dostępne na polskim rynku nie różniły się między sobą znacząco pod względem właściwości przeciwutleniających, jednak znacznie odbiegały od uzyskanej i wysuszonej w warunkach domowych papryki jalapeño, która wyróżniała się największą zawartością kapsaicyny oraz najwyższymi wartościami aktywności przeciwutleniającej. Prawdopodobnie miały na to wpływ parametry suszenia i przechowywania papryki. Ponadto przyprawy wytwarzane przemysłowo mogą zawierać dodatek innych substancji, które zwiększają objętość produktu, a jednocześnie obniżają jakość końcowego wyrobu. Na podstawie przeprowadzonych badań stwierdzono, że przyprawy zawierające ostrą paprykę mogą być dobrym źródłem związków przeciwutleniających w diecie.

Słowa kluczowe: papryka ostra, polifenole, kapsaicyna, kapsaicynoidy, właściwości przeciwutleniające, SHU

\section{Wprowadzenie}

Od dłuższego czasu obserwuje się propagowanie zdrowego stylu życia przejawiającego się nie tylko aktywnością fizyczną, ale także spożywaniem żywności naturalnej

Mgr farm. M. Woźniak, Koło Naukowe Free Radicals, dr P. Siudem, dr hab. K. Paradowska, Katedra Farmacji Fizycznej i Bioanalizy, Wydz. Farmaceutyczny, Warszawski Uniwersytet Medyczny, ul. Banacha 1,02-097Warszawa.Kontakt: pawel.siudem@wum.edu.pl 
o właściwościach odżywczych i prozdrowotnych. Działania takie wpisują się w profilaktykę zdrowia. Produktami pochodzenia naturalnego, które mogą wspomagać działanie prozdrowotne żywności, są przyprawy.

Przyprawy to naturalne lub przetworzone części roślin zielarskich używane w kuchni jako dodatki do żywności. Ze względu na swoją różnorodność, możliwości wykorzystania oraz skład chemiczny nie zostały jednoznacznie zdefiniowane. Często są to mieszanki wieloskładnikowe zawierające obok przypraw roślinnych substancje smakowo-zapachowe (inne niż przyprawy roślinne), substancje wzmacniające smak, produkty przyprawowe, dodatki funkcjonalne [5]. Surowcami przyprawowymi mogą być różne części anatomiczne roślin: owoce, nasiona, liście, a także kwiaty, korzenie i kłącza. Ze względu na pochodzenie wyróżnia się przyprawy rodzime (cebula, czosnek, gorczyca czy majeranek) i importowane (kardamon, pieprz czarny czy goździkowiec korzenny [16]).

W przetwórstwie rolno-spożywczym przyprawy odgrywają ważną rolę, gdyż nadają potrawom barwę i aromat, a także przedłużają ich trwałość oraz wzbogacają walory smakowe. Wynika to $\mathrm{z}$ obecności w nich związków należących do różnych grup chemicznych (np. alkaloidów czy terpenów wchodzących w skład olejków eterycznych). Niektóre przyprawy pobudzają apetyt, nasilają czynności wydzielnicze przewodu pokarmowego. Inne regulują perystaltykę jelit i przyspieszają wydalanie niestrawionego pokarmu. Mogą działać pobudzająco czy uspokajająco, jak również bakteriostatycznie lub bakteriobójczo [30]. Działanie przeciwdrobnoustrojowe i przeciwutleniające przypraw często skorelowane jest $\mathrm{z}$ występującymi w nich fitozwiązkami [26]. W celu zapewnienia bezpieczeństwa żywności stosuje się je jako dodatki o charakterze hamującym namnażanie mikroorganizmów [9].

Papryka ostra, pieprzowiec (Capsicum ssp.), zwana też chili jest powszechnie stosowana w kuchni [2]. Pochodzi z Ameryki Łacińskiej, a pierwsze informacje na jej temat wywodzą się z czasów prekolumbijskich. Obecnie jako główne źródło papryki uznaje się 5 gatunków: C. annuum, C. chinense, C. baccatum, C. frutescens, C. pubescens [7]. Gatunki te ceni się za intensywny ostry smak i wyrazisty aromat owoców. Mogą one również wykazywać właściwości prozdrowotne.

Owoc pieprzowca (Capsici fructus) został zdefiniowany w Farmakopei Polskiej XI [25] jako: wysuszone i dojrzałe owoce Capsicum annum L. var minimum (Miller) Heiser i Capsicum frutescens L., w których zawartość sumy kapsaicynoidów w przeliczeniu na kapsaicynę jest nie mniejsza niż $0,4 \%$. W FP XI wymienione są też produkty z owoców pieprzowca: oleożywica oczyszczona i standaryzowana (Capsici oleoresina rafinata et normata), nalewka standaryzowana (Capsici tinctura normata) i gęsty wyciąg standaryzowany (Capsici extractum spissum normatum). 
Właściwości prozdrowotne Capsici fructus determinują związki: kapsaicynoidy (dominuje kapsaicyna), związki polifenolowe, w tym flawonoidy (np. 7-glukozyd luteoliny), karotenoidy (kapsantyna, $\beta$-karoten) i witamina C [1].

Kapsaicyna jest głównym związkiem alkaloidowym zawartym w owocach pieprzowca. Alkaloidy produkowane przez rośliny jako metabolity wtórne często wykazują różnokierunkową aktywność biologiczną. Kapsaicyna jest znana głównie jako związek odpowiedzialny za pikantny smak potraw [22], może jednak być również stosowana w farmacji [7]. Związek ten jest odpowiedzialny za działanie przeciwbólowe i przeciwbakteryjne, obniżanie ciśnienia krwi, nasilanie spalania tkanki tłuszczowej, działanie gastroprotekcyjne, a także przeciwutleniające [13]. Działanie przeciwutleniające wykazują też zawarte $\mathrm{w}$ papryce polifenole, $\mathrm{w}$ tym flawonoidy i witamina $\mathrm{C}$. Zarówno zawartość tych związków, jak i właściwości przeciwutleniające różnicują gatunki papryki [5].

Ze względu na wzrost spożywania pikantnych potraw i szeroki asortyment przypraw zawierających paprykę ostrą celowe jest badanie jakości i składu przypraw obecnych na rynku.

Celem pracy było określenie zawartości związków polifenolowych, w tym flawonoidów, kapsaicynoidów oraz właściwości przeciwutleniających i zdolności redukowania jonów żelaza w przyprawach zawierających paprykę ostrą, dostępnych na polskim rynku.

\section{Material i metody badań}

Materiałem doświadczalnym były przyprawy zawierające Capsicum spp.: pieprz cayenne, chili jalapeño, chili peperoncini - marki Kotanyi (Kotanyi, Austria), papryka ostra i chili - marki Kamis (Mc Cormik, Polska), papryka ostra marki Prymat (Prymat Sp. z o.o., Polska) i papryka ostra marki Herbes (ZPH Herbes Wiesław Sikorski, Polska). Zakupione przyprawy były oznakowane aktualnym terminem przydatności do spożycia. Ostatnią próbę stanowiła papryka Capsicum annuum var. jalapeño z uprawy domowej. Zakupione nasiona odmiany jalapeño wysiewano w marcu (w temperaturze pokojowej). Uprawę prowadzono w glebie ogrodniczej uniwersalnej, wewnątrz budynku (okno wschodnie), a po wykiełkowaniu i przepikowaniu roślin dalszą uprawę prowadzono na zewnątrz budynku w warunkach wilgotności i temperatury typowych dla klimatu umiarkowanego. Owoce zbierano w sierpniu, a następnie suszono w temp. 20 $\pm 2{ }^{\circ} \mathrm{C}$. Charakterystykę przypraw przedstawiono w tab. 1 .

Przed przystąpieniem do badań przyprawy P5, P6 i P8 rozcierano w moździerzu do postaci proszku. W celu doboru odpowiedniego rozpuszczalnika początkowo wykonywano ekstrakcje z użyciem metanolu, acetonu i etanolu o stężeniu 70 i $98 \%$. Na podstawie zawartości związków polifenolowych w tych ekstraktach jako najefektywniejszy rozpuszczalnik do przygotowania docelowych ekstraktów wybrano 70- 
procentowy etanol. Do wykonania każdego ekstraktu odważano 3,000 g przyprawy i rozpuszczano w $20 \mathrm{ml}$ 70-procentowego etanolu. Ekstrakty umieszczano na $10 \mathrm{~min}$ w myjce ultradźwiękowej Sonic-2 (Polsonic, Polska) o parametrach: moc układu grzania $-150 \mathrm{~W}$, moc ultradźwiękowa $-2 \times 100 \mathrm{~W}$, częstotliwość generatora $-40 \mathrm{KHz}$, a następnie wytrząsano je przez $2 \mathrm{~h} \mathrm{w}$ temp. $20 \pm 2{ }^{\circ} \mathrm{C}(250 \mathrm{obr} . / \mathrm{min})$ w wytrząsarce SK-O330-Pro (DragonLab, Polska). Następnie przesączano przez sączki bibułowe i otrzymywano klarowne roztwory. Każdy ekstrakt wykonano w dwóch powtórzeniach.

Tabela 1. Charakterystyka badanych przypraw zawierających Capsicum spp.

Table 1. Characteristics of analysed spices containing Capsicum spp.

\begin{tabular}{|c|c|c|c|c|}
\hline $\begin{array}{l}\text { Próba } \\
\text { Sample }\end{array}$ & $\begin{array}{l}\text { Nazwa produktu } \\
\text { Name of product }\end{array}$ & $\begin{array}{c}\text { Marka produktu } \\
\text { Product brand }\end{array}$ & $\begin{array}{c}\text { Opis producenta } \\
\text { Description by manufacturer }\end{array}$ & $\begin{array}{l}\text { Postać } \\
\text { Form }\end{array}$ \\
\hline P1 & $\begin{array}{l}\text { Pieprz cayenne } \\
\text { mielony } \\
\text { Ground cayenne } \\
\text { pepper }\end{array}$ & Kotanyi & $\begin{array}{c}\text { Dojrzałe pomarańczowo-czerwone } \\
\text { papryczki chili w postaci zmielonego } \\
\text { proszku / Ripe orange-red chili peppers in } \\
\text { the form of ground powder }\end{array}$ & $\begin{array}{l}\text { Proszek } \\
\text { Powder }\end{array}$ \\
\hline P2 & $\begin{array}{c}\text { Papryka ostra } \\
\text { mielona } \\
\text { Ground hot pepper }\end{array}$ & Kamis & $\begin{array}{l}\text { Papryka ostra }-65 \% \text {, odthuszczona } \\
\text { Hot pepper }-65 \% \text {, degreased }\end{array}$ & $\begin{array}{l}\text { Proszek } \\
\text { Powder }\end{array}$ \\
\hline P3 & $\begin{array}{l}\text { Chili pieprz } \\
\text { cayenne } \\
\text { Chili cayenne } \\
\text { pepper } \\
\end{array}$ & Kamis & $\begin{array}{c}\text { Ostra mieszanka chili z thuczonymi } \\
\text { owocami papryki gałęzistej } \\
\text { Spicy mix of chilli and mashed fruits of } \\
\text { Capsicum frutescens } \\
\end{array}$ & $\begin{array}{l}\text { Proszek } \\
\text { Powder }\end{array}$ \\
\hline P4 & $\begin{array}{c}\text { Papryka ostra } \\
\text { mielona } \\
\text { Ground hot pepper }\end{array}$ & Prymat & $\begin{array}{c}\text { Papryka ostra mielona pochodząca } \\
\text { z Hiszpanii / Ground hot pepper originating } \\
\text { from Spain } \\
\end{array}$ & $\begin{array}{l}\text { Proszek } \\
\text { Powder }\end{array}$ \\
\hline P5 & $\begin{array}{l}\text { Chili jalapeño } \\
\text { kruszone } \\
\text { Crushed chilli } \\
\text { jalapeño }\end{array}$ & Kotanyi & $\begin{array}{c}\text { Papryczka chili jalapeño pochodząca } \\
\text { z Meksyku. Stopień ostrości w skali } \\
\text { Scoville'a } 6400 \div 12000 \text { / Jalapeño chili } \\
\text { pepper originating from Mexico. Scoville } \\
\text { Heat Units } 6400 \div 12000\end{array}$ & $\begin{array}{l}\text { Części } \\
\text { owoców } \\
\text { Pieces of } \\
\text { fruit }\end{array}$ \\
\hline P6 & $\begin{array}{l}\text { Chili peperoncini } \\
\text { całe / Whole chilli } \\
\text { peperoncini }\end{array}$ & Kotanyi & $\begin{array}{c}\text { Chili peperoncini. Stopień ostrości w skali } \\
\text { Scoville'a } 100000 \div 192000 \\
\text { Chili peperoncini. Scoville Heat Units } \\
100000 \div 192000\end{array}$ & $\begin{array}{l}\text { Całe owoce } \\
\text { Whole fruits }\end{array}$ \\
\hline P7 & $\begin{array}{l}\text { Papryka ostra } \\
\text { Hot pepper }\end{array}$ & Herbes & $\begin{array}{c}\text { Papryka ostra w postaci sproszkowanej } \\
\text { pochodząca z Hiszpanii / Hot powdered } \\
\text { pepper originating from Spain }\end{array}$ & $\begin{array}{l}\text { Proszek } \\
\text { Powder }\end{array}$ \\
\hline P8 & $\begin{array}{l}\text { Capsicum anпuиm } \\
\text { var. jalapeño }\end{array}$ & $\begin{array}{l}\text { Uprawa } \\
\text { domowa } \\
\text { Indoor } \\
\text { cultivation }\end{array}$ & $\begin{array}{l}\text { Wysuszone owoce papryki } \\
\text { Dried pepper fruits }\end{array}$ & $\begin{array}{l}\text { Całe owoce } \\
\text { Whole fruits }\end{array}$ \\
\hline
\end{tabular}


W ekstraktach etanolowych oznaczano całkowitą zawartość polifenoli (TP), całkowitą zawartość flawonoidów (TF) oraz wykonywano dwa testy na oznaczanie właściwości przeciwutleniających: FRAP i z użyciem rodnika DPPH: Wykonywano także spektrofotometryczne oznaczanie sumy kapsaicynoidów w przeliczeniu na kapsaicynę. Oznaczenia spektrofotometryczne wykonywano przy użyciu spektrofotometru UV-VIS Evolution 60S (Thermo Scientific, USA) w temp. $20 \pm 2{ }^{\circ} \mathrm{C}$. Wyniki analiz przeliczano na gram suchej masy przyprawy. Wszystkie oznaczenia wykonano w 3 powtórzeniach.

Oznaczanie całkowitej zawartości polifenoli (TP) wykonywano spektrofotometrycznie metodą Folina-Ciocalteu'a [18]. Pobierano $20 \mu 1$ odpowiednio rozcieńczonej próbki do kuwety, dodawano kolejno $1,58 \mathrm{ml}$ wody dejonizowanej, $100 \mu 1$ odczynnika Folina-Ciocalteu'a i po wymieszaniu dodawano $200 \mu 1$ 20-procentowego roztworu wodorowęglanu sodu. Próbkę wstawiano do termostatu $\left(40^{\circ} \mathrm{C}\right)$. Po upływie $20 \mathrm{~min}$ mierzono jej absorbancję przy długości fali $\lambda=765 \mathrm{~nm}$ wobec próby zerowej. Wyniki wyrażano jako ekwiwalent kwasu galusowego (GAE) na podstawie krzywej wzorcowej: $y=1,059 x+0,004\left(R^{2}=0,998\right)$, gdzie: $y$ - wartość absorbancji, $x$ - stężenie kwasu galusowego $[\mathrm{mg} / \mathrm{g}]$.

Oznaczanie całkowitej zawartości flawonoidów (TF) wykonywano metodą, którą opracowali Kim i wsp. [14]. Do kuwety pomiarowej dodawano 1,4 $\mathrm{ml}$ dejonizowanej wody, $100 \mu \mathrm{l}$ próbki/wzorca/dejonizowanej wody, $60 \mu \mathrm{l}$ 5-procentowego $\mathrm{NaNO}_{3}$, $60 \mu 1$ 10-procentowego $\mathrm{AlCl}_{3}$, inkubowano w temp. $25{ }^{\circ} \mathrm{C}$ przez $5 \mathrm{~min}$, a następnie dodawano $0,4 \mathrm{ml} 1 \mathrm{M} \mathrm{NaOH}$. Pomiar absorbancji wykonywano wobec próby zerowej przy długości fali $\lambda=510 \mathrm{~nm}$.

Zawartość flawonoidów obliczano na podstawie krzywej wzorcowej: $\mathrm{y}=1,408 \mathrm{x}$ 0,003 $\left(\mathrm{R}^{2}=0,989\right)$, gdzie: $\mathrm{y}$ - wartość absorbancji, $\mathrm{x}$ - stężenie katechiny $[\mathrm{mg} / \mathrm{ml}]$ i wyrażano jako ekwiwalent katechiny (CE) w ekstrakcie [mg/g].

Właściwości przeciwutleniające oznaczano spektrofotometrycznie według procedury, którą opracowali Sanny i wsp. [27]. W oznaczeniu zastosowano trwały rodnik DPPH (1,1-difenylo-2-pikrylohydrazylowy). Do $100 \mu 1$ odpowiednio rozcieńczonego ekstraktu dodawano $1900 \mu 1$ rozcieńczonego roztworu DPPH'. Odstawiano do inkubacji w temp. $20 \pm 2{ }^{\circ} \mathrm{C}$ na $20 \mathrm{~min}$, po czym mierzono absorbancję (długość fali $\lambda=515 \mathrm{~nm}$ ) próbek zawierających ekstrakty względem próbki bez dodatku ekstraktu. Wyniki wyrażano jako ilość zneutralizowanego rodnika przez ekstrakt w mg/g s.m.

Zdolność redukcji 1 mola żelaza z III stopnia utlenienia na II - FRAP (Ferric Reducing Ability) wykonywano zgodnie z procedurą, którą opracowali Benzie i Strain [3]. Do $1 \mathrm{ml}$ reagenta FRAP dodawano $0,05 \mathrm{ml}$ odpowiednio rozcieńczonego ekstraktu i inkubowano przez 4 min w temp. $37^{\circ} \mathrm{C}$. Absorbancję mierzono wobec próby zerowej przy długości fali $\lambda=593 \mathrm{~nm}$. Wyniki wyrażano jako ilość zredukowanych jonów żelaza przez ekstrakt w $\mathrm{Fe}^{2+} \mathrm{mmol} / \mathrm{g}$ s.m. 
Zawartość kapsaicynoidów w przeliczeniu na kapsaicynę oznaczano spektrofotometrycznie [24]. Na podstawie widma absorpcyjnego wzorca kapsaicyny ustalono maksimum absorbancji przy długości fali $\lambda=280 \mathrm{~nm}$. Zawartość kapsaicyny obliczano na podstawie krzywej wzorcowej: $\mathrm{y}=0,0097 \mathrm{x}+0,0149\left(\mathrm{R}^{2}=0,998\right)$. Wyniki wyrażano w mg sumy kapsaicynoidów w przeliczeniu na kapsaicynę/g s.m.

Do statystycznego opracowania wyników zastosowano jednoczynnikową analizę wariancji ANOVA. Istotność różnic między wartościami średnimi weryfikowano testem Tukeya $(\mathrm{p}<0,05)$. Obliczenia wykonano przy użyciu programu Microsoft Excel $^{\mathrm{TM}} 2010$ oraz Statistica 13.

\section{Wyniki i dyskusja}

Całkowita zawartość polifenoli w suchej masie prób P1 - P7 zawierała się w przedziale $9,17 \div 11,17 \mathrm{GAE} / \mathrm{g}$ s.m., natomiast w papryce P8, pochodzącej z uprawy w warunkach domowych, stwierdzono większą zawartość polifenoli ogółem, tj. średnio 17,49 mg GAE/g s.m. papryki (tab. 2). Całkowita zawartość flawonoidów w ekstraktach z przypraw komercyjnych wynosiła $1,33 \div 2,13$ ekwiwalentu CE/g s.m. Ekstrakt z papryki $\mathrm{P} 8$ ponownie charakteryzował się najwyższą wartością $-2,75$ ekwiwalentu $\mathrm{CE} / \mathrm{g}$ s.m. W teście DPPH` oznaczano ilość rodnika zneutralizowanego przez ekstrakt. Efektem działania przypraw P1 - P7 było 14,9 $\div 22,2 \mathrm{mg}$ zneutralizowanego rodnika/g s.m. W przypadku papryki z uprawy domowej wynik ten był wyższy średnio o $140 \div$ 260 \% i wyniósł aż 53,62 mg zneutralizowanego rodnika/g s.m. W teście FRAP wykazano zdolność redukcji 1 mola żelaza z III stopnia utlenienia na II na poziomie $0,175 \div$ 0,439 $\mathrm{mmol} \mathrm{Fe}{ }^{2+} / \mathrm{g} \mathrm{s.m}$. - ekstrakty z przypraw P1 - P7 i 0,588 mmol Fe

$\mathrm{Na}$ wartości TP, TF, DPPH i FRAP wpływa wiele czynników. Moo-Huchin i wsp. [21], Conforti i wsp. [10], Shaimaa i wsp. [28] potwierdzają, że podczas dojrzewania owoców (w tym chili) zwiększa się zawartość polifenoli i flawonoidów. Wyższe wyniki w teście DPPH osiągają jednak owoce zielone niż te o pomarańczowej barwie [7]. Również w badaniach własnych przyprawa P5 (o zielonej barwie) wykazywała wyższe wartości $\mathrm{w}$ teście $\mathrm{DPPH}{ }^{\bullet}$ oraz FRAP $\mathrm{w}$ porównaniu z pozostałymi przyprawami przemysłowymi. Może to być związane $\mathrm{z}$ większą zawartością chlorofilu w zielonych owocach i wskazuje, że zdolność do neutralizowania wolnych rodników zależy nie tylko od całkowitej zawartości polifenoli i flawonoidów, ale również od innych związków obecnych w owocach.

Gatunek roślin, z jakich pozyskuje się owoce do sporządzenia przypraw ma także wpływ na zawartość TP i TF oraz wynik testu DPPH*. Olatunij i wsp. [23] odnotowali największe różnice pod względem zawartości flawonoidów, a dotyczyły one ekstraktów etanolowych z papryki odmiany C. annuum var. grossum - średnio 1630,53 ekwiwalentu QE (ekwiwalentu kwercetyny)/g s. m.) i C. frutescens var. baccatum - średnio 867,241 ekwiwalentu QE/g s.m.). 
Tabela 2. Wyniki całkowitej zawartości polifenoli, całkowitej zawartości flawonoidów, testu DPPH` i testu FRAP w badanych przyprawach zawierających Capsicum spp.

Table 2. Results of total contents of polyphenols and flavonoids in and of DPPH ${ }^{\circ}$ and FRAP tests in analysed spices containing Capsicum spp.

\begin{tabular}{|c|c|c|c|c||}
\hline $\begin{array}{c}\text { Próba } \\
\text { Sample }\end{array}$ & $\begin{array}{c}\text { TP } \\
\text { [mg GAE/g s.m. }] \\
{[\mathrm{mg} \mathrm{GAE} / \mathrm{g} \mathrm{d.m} .]}\end{array}$ & $\begin{array}{c}\text { TF } \\
{[\mathrm{mg} \mathrm{CE} / \mathrm{g} \mathrm{s.m} .]} \\
{[\mathrm{mg} \mathrm{CE} / \mathrm{g} \mathrm{d} . \mathrm{m} .]}\end{array}$ & $\begin{array}{c}\text { DPPH } \\
{[\mathrm{mg} / \mathrm{g} \mathrm{s.m} .]} \\
{[\mathrm{mg} / \mathrm{g} \mathrm{d} . \mathrm{m} .]}\end{array}$ & $\begin{array}{c}\text { FRAP } \\
{\left[\mathrm{Fe}^{2+} \mathrm{mmol} / \mathrm{g} \mathrm{s.m.}\right]} \\
{\left[\mathrm{Fe}^{2+} \mathrm{mmol} / \mathrm{g} \mathrm{d.m} .\right]}\end{array}$ \\
\hline P1 & $9,51^{\mathrm{a}} \pm 0,46$ & $1,42^{\mathrm{a}, \mathrm{b}} \pm 0,01$ & $15,9^{\mathrm{a}, \mathrm{b}} \pm 0,2$ & $0,175^{\mathrm{d}} \pm 0,017$ \\
\hline P2 & $10,42^{\mathrm{a}, \mathrm{b}} \pm 0,29$ & $2,07^{\mathrm{c}} \pm 0,07$ & $22,2^{\mathrm{c}} \pm 0,2$ & $0,249^{\mathrm{a}, \mathrm{b}} \pm 0,008$ \\
\hline P3 & $10,34^{\mathrm{a}, \mathrm{b}} \pm 0,45$ & $1,47^{\mathrm{b}} \pm 0,03$ & $16,4^{\mathrm{b}} \pm 0,5$ & $0,297^{\mathrm{c}} \pm 0,006$ \\
\hline P4 & $9,83^{\mathrm{a}, \mathrm{b}} \pm 0,43$ & $1,33^{\mathrm{a}} \pm 0,01$ & $15,7^{\mathrm{a}, \mathrm{b}} \pm 0,9$ & $0,217^{\mathrm{b}} \pm 0,003$ \\
\hline P5 & $11,17^{\mathrm{b}} \pm 0,79$ & $1,78^{\mathrm{d}} \pm 0,03$ & $20,1^{\mathrm{d}} \pm 0,4$ & $0,349^{\mathrm{e}} \pm 0,020$ \\
\hline P6 & $11,00^{\mathrm{b}} \pm 0,41$ & $2,13^{\mathrm{c}} \pm 0,05$ & $14,9^{\mathrm{a}} \pm 0,3$ & $0,439^{\mathrm{f}} \pm 0,008$ \\
\hline P7 & $9,17^{\mathrm{a}} \pm 0,13$ & $1,43^{\mathrm{a}, \mathrm{b}} \pm 0,06$ & $17,8^{\mathrm{e}} \pm 0,5$ & $0,278^{\mathrm{a}, \mathrm{c}} \pm 0,014$ \\
\hline P8 & $17,49^{\mathrm{c}} \pm 0,91$ & $2,75^{\mathrm{d}} \pm 0,03$ & $53,6^{\mathrm{f}} \pm 0,0$ & $0,588^{\mathrm{g}} \pm 0,013$ \\
\hline MS & 0,280 & 0,019 & 0,210 & 0,0001 \\
\hline
\end{tabular}

Objaśnienia / Explanatory notes:

$\mathrm{TP}$ - całkowita zawartość polifenoli / total content of polyphenols; TF - całkowita zawartość flawonoidów / total content of flavonoids. W tabeli przedstawiono wartości średnie \pm odchylenia standardowe / Table shows mean values \pm standard deviations; $\mathrm{n}=3$; a - $\mathrm{g}$ - wartości średnie w kolumnach oznaczone różnymi literami różnią się statystycznie istotnie przy $\mathrm{p} \leq 0,05 /$ mean values in columns denoted by different letters differ statistically significantly at $\mathrm{p} \leq 0.05$; MS - średni kwadrat odchyleń między grupami / mean square of deviations among groups.

W badaniach różnych odmian C. annuum zauważono, że papryka Caribe zawierała najwięcej polifenoli, a papryka jalapeño - najmniej. Medina-Juárez i wsp. [19] wykazali, że papryka Caribe charakteryzowała się również największą zawartością flawonoidów (60,36 ekwiwalentu QE/100 g s.m.). Podobnie w przypadku testu DPPH wartości pomiarów (wyrażone jako \% inhibicji $\mathrm{DPPH}^{\circ}$ ) wahały się od 8,45 \% - papryka jalapeño do 83,44 \% - papryka Caribe. Producenci przypraw nie podają gatunku i odmiany papryki, z jakiej produkowane są przyprawy. Często ograniczają się do sformułowania „sproszkowany owoc chili”. Utrudnia to porównanie przypraw pod względem pochodzenia. Można jednak zauważyć, że w badaniach własnych próby P5 i P8 były przyprawami o dużej zawartości TP, TF oraz wysokiej aktywności przeciwutleniającej (DPPH` i FRAP) w porównaniu z pozostałymi przyprawami (tab. 2). Obie przyprawy zostały uzyskane z Capsicum annuum var jalapeño. W przytoczonych powyżej badaniach [19] odmiana jalapeño osiągała jednak niższe wartości właściwości przeciwutleniających $\mathrm{w}$ porównaniu $\mathrm{z}$ innymi próbami. Była jednak porównywalna z odmianą Caribe, która może być nawet sześć razy ostrzejsza niż jalapeño. Większa zawartość kapsaicynoidów determinujących ostry smak może wpływać również na zawartość polifenoli. W badaniach własnych ekstrakty z przypraw zawierających pa- 
prykę jalapeño były porównywalne pod względem właściwości przeciwutleniających z przyprawami o podobnej ostrości.

Czynnikiem, który powinien wpływać na zawartość związków polifenolowych (TP) jest sposób uprawy. Chassy i wsp. [8] przeprowadzili badania, w których porównali uprawy klasyczną oraz ekologiczną i nie wykazali, żeby rodzaj uprawy miał wpływ na zawartość polifenoli w owocach papryki. Czynnikiem w znacznym stopniu determinującym zawartość TP w tych badaniach okazał się ponownie gatunek papryki.

Część związków polifenolowych jest nietrwała i podczas procesu suszenia surowca roślinnego ich zawartość może się zmniejszać. Vega-Gálvez i wsp. [31] podają, że początkowa zawartość polifenoli w owocach chili wynosiła 1359 GAE/g świeżej próbki, a podczas suszenia zmniejszyła się poniżej $400 \mathrm{mg}$ GAE/g świeżej próbki. Potwierdzili także, że suszenie zmniejsza zdolności przeciwutleniające określane za pomocą testu DPPH'. Może to być przyczyną zaobserwowanych różnic między próbami P1 P7 a P8 w badaniach własnych. W warunkach przemysłowych czas suszenia ma znaczenie ekonomiczne, dlatego jest skracany przez zastosowanie wyższej temperatury (standardowo ok. $70^{\circ} \mathrm{C}$ ) [4]. Wyniki uzyskane w niniejszej pracy wskazują, że suszona dłużej, ale w temp. $20 \pm 2{ }^{\circ} \mathrm{C}$ papryka wyróżniała się wyższymi wartościami zarówno pod względem całkowitej zawartości polifenoli, jak i flawonoidów oraz wykazywała większą aktywność przeciwutleniającą.

Duży wpływ na zawartość TP oraz na właściwości przeciwutleniające przypraw ma przechowywanie. Kozłowska i wsp. [15] dowiedli, że podczas przechowywania przypraw w temp. $-18{ }^{\circ} \mathrm{C}$ następuje zmniejszenie zawartości polifenoli ogółem oraz obniżenie pojemności przeciwutleniającej w badanych ekstraktach. Nie bez znaczenia może być też forma, w jakiej przechowuje się przyprawy. W badaniach własnych wszystkie przyprawy były przechowywane w szczelnie zamkniętych opakowaniach, jednak tylko próbki P6 i P8 jako całe, niesproszkowane owoce (tab. 1). Przyprawy P6 i P8 wyróżniały się dużą zawartością związków polifenolowych i flawonoidów, co wskazuje, że przechowywanie suszonych owoców w całości może korzystnie wpływać na trwałość tych związków.

Zarówno proces suszenia, jak i przechowywanie przypraw wpływają na mniejszą zawartość TP i TF w przyprawach w porównaniu ze świeżymi owocami pieprzowca $[5,10,19]$. Wyniki badań uzyskane w niniejszej pracy (wartość średnia przypraw rynkowych to 10,20 ekwiwalentu GAE/g s.m.) korespondują z wynikami, które uzyskali Lu i wsp. [17]. Stwierdzili oni bowiem, że zawartość TP w suszonej papryce wynosiła 9,30 ekwiwalentu GAE/g s.m.

Polifenole wykazują działanie przeciwutleniające [33], dlatego ogólna zawartość tych związków w danej próbce powinna wpływać na wyniki testów przeciwutleniających. Potwierdza to współczynnik determinacji $\mathrm{R}^{2}=0,92$, odnoszący się do zależności zawartości TP od wartości testu DPPH` (rys. 1). Sricharoen i wsp. [29] podają wysoką 
determinację tych zmiennych $\left(\mathrm{R}^{2}=0,96\right)$, podczas gdy Bogusz i wsp. [5] oraz MooHuchin i wsp. [21] uzyskali niższe wartości $\mathrm{R}^{2}$, odpowiednio: 0,73 i 0,77 .

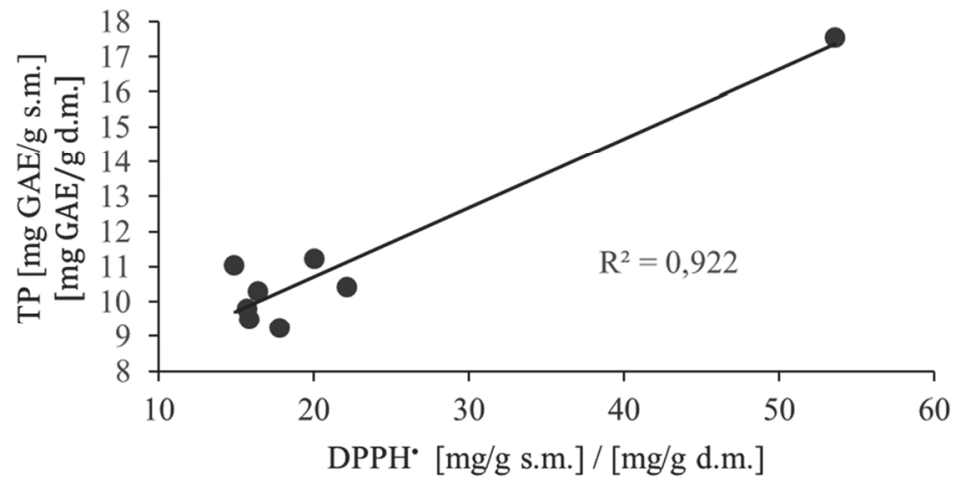

Rys. 1. Zależność pomiędzy wartościami testu DPPHª a całkowitą zawartością polifenoli (TP) w badanych przyprawach zawierających Capsicum spp.

Fig. 1. Relationship between DPPH test values and total content of polyphenols (TP) in analysed spices containing Capsicum spp.

Zależność zawartości TP od wartości testu FRAP w badaniach własnych charakteryzowała się współczynnikiem determinacji $\mathrm{R}^{2}=0,90$. Bogusz i wsp. [5], MooHuchin i wsp. [21], Lu i wsp. [17] oraz Sricharoen i wsp. [29] podają, że $\mathrm{R}^{2}$ takiej zależności wynosi odpowiednio: 0,$92 ; 0,96 ; 0,93 ; 0,83$. Z kolei współczynnik determinacji pomiędzy zawartością całkowitą flawonoidów (TF) a wartościami testu DPPH w niniejszych badaniach wyniósł 0,88 .

Zależność całkowitej zawartości TF od wartości testu FRAP skutkowała współczynnikiem determinacji $R^{2}=0,73$. Firuzi i wsp. [12] otrzymali wynik $R^{2}=0,82$ przy oznaczeniu TF metodą woltamperometryczną.

Zarejestrowano widmo absorpcyjne UV-VIS kapsaicyny i wyznaczono maksimum jej absorbancji. Zarejestrowano też widma ekstraktów. Na rys. 2. przedstawiono przykładowe widma absorpcyjne kapsaicyny i ekstraktów P6 i P8. Wyniki oznaczania całkowitej zawartości kapsaicynoidów w przeliczeniu na kapsaicynę przedstawiono w tab. 3. Kapsaicyna wpływa na ostrość danej przyprawy. Stopień ostrości przypraw określa skala SHU. Czysta kapsaicyna charakteryzuje się najwyższą wartością SHU wynoszącą 16000000 [7]. 


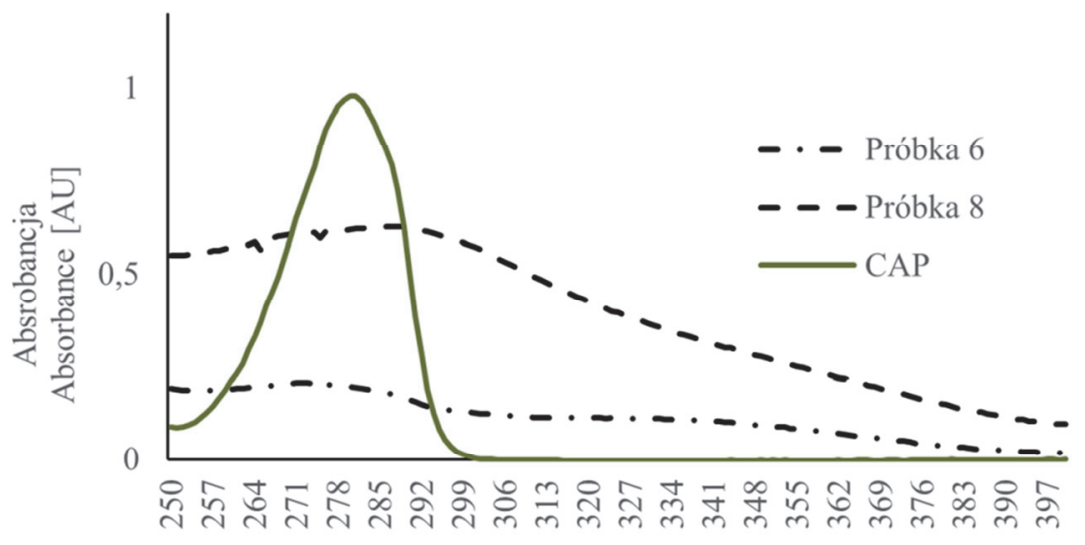

Dhugość fali / Wavelenght [nm]

Objaśnienia / Explanatory notes:

CAP - kapsaicyna / capsaicin; maksimum absorbancji kapsaicyny $-\lambda=280 \mathrm{~nm} /$ maximum absorption for capsaicin $-\lambda=280 \mathrm{~nm}$.

Rys. 2. Przykładowe widma absorpcyjne ekstraktów z prób przypraw P6, P8 i wzorca kapsaicyny

Fig. 2. Examples of UV-VIS spectra of extracts made of P6 and P8 spice samples and of model capsai$\operatorname{cin}$

Tabela 3. Całkowita zawartość kapsaicynoidów i wartość SHU badanych przypraw zawierających Capsicum spp.

Table 3. Total amount of capsaicinoids and SHU value of analysed spices containing Capsicum spp.

\begin{tabular}{||c|c|c|c|c|c|c|c|c||}
\hline $\begin{array}{c}\text { Próba } \\
\text { Sample }\end{array}$ & P1 & P2 & P3 & P4 & P5 & P6 & P7 & P8 \\
\hline $\begin{array}{c}\text { Kapsaicynoidy } \\
\text { [mg/g s.m. } \\
\text { Capsaicinoids } \\
\text { [mg/g d.m. }\end{array}$ & $\begin{array}{c}5,64^{\mathrm{a}} \\
\pm 0,14\end{array}$ & $\begin{array}{c}6,77^{\mathrm{b}} \\
\pm 0,26\end{array}$ & $\begin{array}{c}7,19^{\mathrm{b}} \\
\pm 0,18\end{array}$ & $\begin{array}{c}5,27^{\mathrm{a}} \\
\pm 0,24\end{array}$ & $\begin{array}{c}5,48^{\mathrm{a}} \\
\pm 0,14\end{array}$ & $\begin{array}{c}3,92^{\mathrm{c}} \\
\pm 0,06\end{array}$ & $\begin{array}{c}5,73^{\mathrm{a}} \\
\pm 0,17\end{array}$ & $\begin{array}{c}14,97^{\mathrm{d}} \\
\pm 0,58\end{array}$ \\
\hline $\begin{array}{c}\text { Wartość SHU } \\
\text { SHU value }\end{array}$ & 90293 & 108326 & 115039 & 84266 & 87690 & 62726 & 91683 & 239480 \\
\hline \multicolumn{70}{|c||}{0,0698} \\
\hline
\end{tabular}

Objaśnienia / Explanatory notes:

W tabeli przedstawiono wartości średnie \pm odchylenia standardowe / Table shows mean values \pm standard deviations; $\mathrm{n}=3$; $\mathrm{a}, \mathrm{b}$ - wartości średnie oznaczone różnymi literami różnią się statystycznie istotnie przy $\mathrm{p} \leq 0,05$ / mean values denoted by different letters differ statistically significantly at $\mathrm{p} \leq 0.05$; MS - średni kwadrat odchyleń między grupami/ mean square between groups.

Na podstawie całkowitej zawartości kapsaicynoidów wyliczono wartość SHU przypraw (tab. 3). Wykazano, że zarówno próba P6, jak i P8 różniły się statystycznie 
istotnie od wszystkich pozostałych prób. Stwierdzono, że najostrzejszym smakiem cechowała się papryka uzyskana w warunkach domowych.

Na zawartość kapsaicyny i kapsacynoidów w owocach papryki wpływa wiele czynników. Aza-González i wsp. [1] potwierdzają, że C. frutescens i C. chinense zawierają więcej kapsacynoidów niż gatunek $C$. annuum. W skład przypraw komercyjnych mogą wchodzić różne odmiany papryki, co może mieć wpływ na „siłę ostrości”. Fayos i wsp. [11] badali też wpływ czasu dojrzewania owoców na całkowitą zawartość kapsacynoidów. Stwierdzili, że całkowita zawartość kapsaicynoidów w papryce Malagueta wzrasta w ciągu 75 dni do $2,568 \mathrm{mg} / \mathrm{g}$ świeżych owoców, co odpowiada wzrostowi o ponad $300 \% \mathrm{w}$ porównaniu z początkową zawartością kapsaicynoidów. Zawartość kapsaicyny nie jest równomiernie rozmieszczona w owocu. Mokhart i wsp. [20] potwierdzają, że największa zawartość kapsaicyny występuje w łożysku zalążni, następnie w nasionach, a najmniej jest jej w owocni. Wyjaśnia to, dlaczego najostrzejsza była próba P8. Została ona bowiem przygotowana $\mathrm{z}$ całego owocu, razem $\mathrm{z}$ nasionami. Podczas przemysłowej produkcji przypraw może następować oddzielanie owocni od nasion i rozdrabnianie samej owocni [32]. Wszystkie te czynniki mogą wpływać na różnice zawartości kapsaicyny w dostępnych na rynku przyprawach i decydować o poziomie ich ostrości.

\section{Wnioski}

1. Pod względem całkowitej zawartości polifenoli, flawonoidów i kapsaicynoidów oraz determinowanych przez te związki właściwości przeciwutleniających przyprawy pochodzące od różnych producentów nie różniły się od siebie w sposób znaczący.

2. Owoce papryki z uprawy domowej po wysuszeniu w dużym stopniu przewyższały próby przypraw dostępnych na rynku pod względem wszystkich oznaczonych parametrów. Stwierdzono również, że o poziomie badanych parametrów mogła decydować forma, w jakiej przyprawa była przechowywana (proszek po zmieleniu owoców vs całe owoce).

3. Obecność nasion papryki Capsicum spp. w przyprawie powoduje zwiększenie jej ostrego smaku.

4. Wyliczona wartość SHU przypraw potwierdziła, że papryka z uprawy domowej wyróżniała się istotnie pod względem ostrości spośród badanych prób.

\section{Literatura}

[1] Aza-González C., Núñez-Palenius H.G., Ochoa-Alejo N.: Molecular biology of capsaicinoid biosynthesis in chili pepper (Capsicum spp.). Plant Cell. Rep., 2011, 30 (5), 695-706. 
[2] Baenas N., Belović M., Ilic N., Moreno D.A., García-Viguera C.: Industrial use of pepper (Capsicum annum L.) derived products: Technological benefits and biological advantages. Food Chem., 2019, 274, 872-885.

[3] Benzie I.F., Strain J.J.: The ferric reducing ability of plasma (FRAP) as a measure of "antioxidant power": The FRAP assay. Anal. Biochem., 1996, 239 (1), 70-76.

[4] Bianchi G., Lo Scalzo R.: Characterization of hot pepper spice phytochemicals, taste compounds content and volatile profiles in relation to the drying temperature. J. Food Biochem., 2018, 42 (6), \#12675.

[5] Bogusz S. Jr., Libardi S.H., Dias F.G., Coutinho J.P., Bochi V.C., Rodrigues D., Melo A., Godoy H.T.: Brazilian Capsicum peppers: Capsaicinoid content and antioxidant activity. J. Sci. Food Agric., 2018, 98 (1), 217-224.

[6] Bortnowska G., Kałuzna-Zajaczkowska J.. Preferencje wyboru przypraw sypkich do potraw przez osoby pracujące zawodowo z uwzględnieniem innowacyjnych zmian w ich produkcji. Rocz. PZH, 2011, 62 (4), 445-452.

[7] Chapa-Oliver A.M., Mejía-Teniente L.: Capsaicin: From plants to a cancer-suppressing agent. Molecules, 2016, 21 (8), 931-945.

[8] Chassy A.W., Bui L., Renaud E.N.C., van Horn M., Mitchell A.E.: Three-year comparison of the content of antioxidant microconstituents and several quality characteristics in organic and conventionally managed tomatoes and bell peppers. J. Agric. Food Chem., 2006, 54 (21), 8244-8252.

[9] Chattopadhyay R.R., Bhattacharyya S.K.: Herbal spices as alternative antimicrobial food preservatives: An update. Pharmacognosy Rev., 2007, 1 (2), 239-247.

[10] Conforti F., Statti G.A., Menichini F.: Chemical and biological variability of hot pepper fruits (Capsicum annuum var. acuminatum L.) in relation to maturity stage. Food Chem., 2007, 102 (4), 10961104.

[11] Fayos O., De Aguiar A.C., Jiménez-Cantizano A., Ferreiro-González M., Garcés-Claver A., Martínez J., Mallor C., Ruiz-Rodríguez A., Palma M., Barroso C.G., Barbero G.F.: Ontogenetic variation of individual and total capsaicinoids in Malagueta peppers (Capsicum frutescens) during fruit maturation. Molecules, 2017, 22 (5), 736-748.

[12] Firuzi O., Lacanna A., Petrucci R., Marrosu G., Saso L.: Evaluation of the antioxidant activity of flavonoids by "ferric reducing antioxidant power" assay and cyclic voltammetry. Biochim. Biophys. Acta, 2005, 1721 (1-3), 174-184.

[13] Ilie M.A., Caruntu C., Tampa M., Georgescu S.R., Matei C., Negrei C., Rodica-Mariana I., Constantin C., Neagu M., Boda D.: Capsaicin: Physicochemical properties, cutaneous reactions and potential applications in painful and inflammatory conditions. Experim. Therap. Med., 2019, 18 (2), 916-925.

[14] Kim D.O., Jeong S.W., Lee C.Y.: Antioxidant capacity of phenolic phytochemicals from various cultivars of plums. Food Chem., 2003, 81 (3), 321-326.

[15] Kozłowska M., Ścibisz I.: Badanie zawartości polifenoli i aktywności przeciwutleniającej ekstraktów z roślin przyprawowych podczas ich przechowywania. Bromat. Chem. Toksykol. 2012, XLV (3), 358-360.

[16] Livarda A.: Spicing up life in northwestern Europe: Exotic food plant imports in the Roman and medieval world. Vegetation History and Archaeobotany, 2001, 20 (2), 143-164.

[17] Lu M., Yuan B., Zeng M., Chen J.: Antioxidant capacity and major phenolic compounds of spices commonly consumed in China. Food Res. Int., 2011, 44 (2), 530-536.

[18] Meda A., Lamien C.A., Romito M., Millogo J.F., Nacoulma O.G.: Determination of the total phenolic, flavonoid and proline contents in Burkina Fasan honey, as well as their radical scavenging activity. Food Chem., 2005. 91 (3), 571-577. 
[19] Medina-Juárez L.Á., Molina-Quijada D.M.A., Toro-Sanchez C.L., Gonzalez-Aguilar G.A., GamezMeza N.: Antioxidant activity of peppers (Capsicum annuum L.) extracts and characterization of their phenolic constituents. Interciencia, 2012, 37 (8), 588-593.

[20] Mokhtar M., Russo M., Cacciola F., Donato P., Giuffrida D., Riazi A., Farnetti S., Dugo P., Mondello L.: Capsaicinoids and carotenoids in Capsicum annuum L.: Optimization of the extraction method, analytical characterization, and evaluation of its biological properties. Food Anal. Meth., 2016, 9 (5), 1381-1390.

[21] Moo-Huchin V.M., de Lourdes Vargas y Vargas M., Tamayo-Cortez J.A., Lopez-Sauri S.A., SauriDuch E., Ortiz Fernandez A.: Solvent extraction and measurement of antioxidant activity and total phenolic content from Capsicum chinense Jacq. Cv Habanero at different maturity stages. Chiang Mai J. Sci., 2019, 46 (4), 661-671.

[22] Naves E.R., de Ávila Silva L., Sulpice R., Araújo W.L., Nunes-Nesi A., Peres L.E.P., Zsögön A.: Capsaicinoids: Pungency beyond capsicum. Trend. Plant Sci., 2019, 24 (2), 109-120.

[23] Olatunji T.L., Afolayan A.J.: Comparative quantitative study on phytochemical contents and antioxidant activities of Capsicum annuum L. and Capsicum frutescens L. Sci. World J., 2019, \#4705140.

[24] Perucka I., Oleszek W.: Extraction and determination of capsaicinoids in fruit of hot pepper Capsicum annuит L. by spectrophotometry and high-performance liquid chromatography. Food Chem., 2000, 71 (2), 287-291.

[25] Farmakopea Polska XI. T. 1. Urząd Rejestracji Produktów Leczniczych, Warszawa 2017, s. 1447.

[26] Sadowska A., Skarżyńska E., Rakowska R., Batogowska J., Waszkiewicz-Robak B.: Substancje bioaktywne w surowcach pochodzenia roślinnego i roślinach zielarskich. Post. Technol. Przetw. Spoż., 2014, 2, 131-135.

[27] Sanna D., Delogu G., Mulas M., Schirra M., Fadda A.: Determination of free radical scavenging activity of plant extracts through DPPH assay: An EPR and UV-VIS study. Food Anal. Method., 2012, 5 (4), 759-766.

[28] Shaimaa G., Mahmoud M.S., Mohamed M.R.: Effect of heat treatment on phenolic and flavonoid compounds and antioxidant activities of some Egyptian sweet and chilli pepper. Nat. Prod. Chem. Res., 2016, 4 (3), 1-6.

[29] Sricharoen P., Lamaiphan N., Patthawaro P., Limchoowong N., Techawonstein S., Chanthai S.: Phytochemicals in Capsicum oleoresin from different varieties of hot chilli peppers with their antidiabetic and antioxidant activities due to some phenolic compounds. Ultrason. Sonochem., 2017, 38, 629-639.

[30] Tapsell L.C., Hemphill I., Cobiac L., Sullivan D.R., Fenech M., Patch C.S., Roodenrys S., Keogh J.B., Clifton P.M., Williams P.G., Fazio V.A., Inge K.E.: Health benefits of herbs and spices: The past, the present, the future. Med. J. Aust., 2006, 185 (4), 1-24.

[31] Vega-Gálvez A., Di Scala K., Rodriguez K., Lemus-Mondaca R., Miranda M., López J., Peraz-Won M.: Effect of air-drying temperature on physico-chemical properties, antioxidant capacity, colour and total phenolic content of red pepper (Capsicum annuum, L. var. Hungarian). Food Chem., 2009, 117 (4), 647-653.

[32] Wang Y., Liu B., Wen X., Li M., Wang K., Ni Y.: Quality analysis and microencapsulation of chili seed oil by spray drying with starch sodium octenylsuccinate and maltodextrin. Powder Technology, 2017, 312, 294-298.

[33] Zhang H., Tsao R.: Dietary polyphenols, oxidative stress and antioxidant and anti-inflammatory effects. Curr. Opinion Food Sci., 2016, 8, 33-42. 


\title{
ANTIOXIDANT PROPERTIES AND THE CONTENT OF CAPSAICINOIDS IN SELECTED SPICES WITH THE ADDITION OF HOT CHILLI PEPPER (CAPSICUM SP.) AVAILABLE ON POLISH MARKET
}

\author{
$\mathrm{Sum}$ m a r y
}

Spices constitute an essential dietary ingredient. Hot peppers are commonly used as a culinary spice. The benefits of using them are not only related to taste, but also to their positive health-promoting effect. This is associated with polyphenolic compounds and other compounds showing antioxidant properties contained in the fruit of hot peppers, such as capsaicin. The objective of the research study was to determine the content of polyphenolic compounds, including flavonoids and capsaicinoids, the antioxidant properties and the ability to reduce iron ions in spices containing hot pepper and available on the Polish market. Aqueous-ethanolic extracts were prepared of 7 different spices labelled by the manufacturers as "hot pepper", "chilli" or "cayenne pepper", and of the home grown jalapeño chilli. In those extracts the total content of polyphenolic compounds (using the Folin-Ciocalteu method) and flavonoids were determined. Also FRAP and DPPH antioxidant tests were performed; the content of capsaicinoids was spectrophotometrically determined and calculated as capsaicin. The spices available on the Polish market did not differ significantly as regards their antioxidant properties, however they differed very much from the home grown and home dried jalapeño chilli that was distinguished by the highest content of capsaicin and the highest antioxidant activity values. Most likely it was the effect of the drying and storing parameters of jalapeño chilli. Moreover, the industrially produced spices may contain other substances added, which increase the volume of the product and at the same time decrease the quality of the final product. Based on the research carried out, it was concluded that the spices with chilli pepper could be a good source of antioxidant compounds in diet.

Key words: hot pepper, polyphenols, capsaicin, capsaicinoids, antioxidant properties, SHU 